\title{
ABSCISIC ACID (ABA) AND THE REGULATION OF SEEDLING GROWTH UNDER STRESS
}

\author{
by Siti Rubiah Zainudin' ${ }^{1}$ and Kamis Awang ${ }^{2}$
}

\begin{abstract}
Xylem sap abscisic acid (ABA) and leaf ABA of Hopea odorata Roxb. and Mimusops elengi L. were measured under conditions of soil compaction and drought to investigate the role of $\mathrm{ABA}$ in the regulation of stomatal conductance. A rapid and substantial increase in xylem sap ABA concentration but not leaf ABA concentration was correlated with soil drying in both species. However, xylem ABA concentration was lower in M. elengi seedlings than in $H$. odorata seedlings. The increase in xylem sap ABA concentration observed at high soil bulk density was correlated with reduced stomatal conductance. These results suggest that xylem ABA may act as a stress signal in the control of stomatal conductance. Reduced xylem ABA levels may explain the lower urban stress tolerance $M$. elengi seedlings relative to $H$. odorata.
\end{abstract}

Key Words. Hopea odorata; Mimusops elengi; soil compaction; drought; stomata conductance; xylem sap abscisic acid; urban environment.

Stomatal conductance is a primary determinant of the net carbon balance and growth of plant species, and, because of its influence on transpirational water loss, stomatal conductance determines the water balance of a plant. Stomata impose a critical control mechanism over water loss and gas exchange between the atmosphere and leaf cells (Liang et al. 1996). Effective stomata control is important for plant growth and survival, especially when water supply is limited. Accumulated evidence has shown that inhibition of leaf growth and stomatal conductance are perhaps the first responses when root systems are exposed to stress conditions, such as drought, flooding, and soil compaction (Passioura 1988; Davies and Zhang 1991; Tardieu and Davies 1993; Hartung et al. 1994). Under these conditions, roots may respond by synthesizing and exporting chemical signals through the transpiration stream to shoots where physiological processes are regulated (Davies and Zhang 1991; Gowing et al. 1993).

Tardieu and Davies (1992) found that the abscisic acid (ABA) content of root tips increased when maize (Zea mays L.) was grown in compacted soil, while the application of $1 \mu \mathrm{M}$ ABA to unstressed seedlings promoted the growth of short, thick roots similar to those produced in response to mechanical impedance (Hartung et al.1994). Stypa (1987) also observed increases in ABA content in both the stunted roots and shoots of maize plants grown in compacted soil under laboratory conditions. In contrast, Lachno et al. (1982) and More et al. (1988) failed to detect any increase in ABA concentration in mechanically impeded roots of maize.

Although the effects of soil compaction have been extensively studied, few experiments have examined the involvement of root-to-shoot signaling in mediating plant responses. Increased xylem sap ABA concentrations and associated reductions in stomatal conductance have been recorded in the shoots of maize plants growing in compacted soil under field conditions (Tardieu et al. 1991). Hartung et al. (1994) also reported increases in xylem sap ABA concentrations in plants subjected to mechanical impedance. It is therefore possible that a root-sourced signal such as ABA may be involved in plant responses to soil compaction.

This experiment was designed to examine the relationship among stomatal conductance, xylem sap ABA concentration, and leaf water potential in two species grown in compacted and unwatered soil.

\section{MATERIALS AND METHODS}

The experiment was a $2 \times 2 \times 2$ factorial design with two species (Hopea odorata and Mimusops elengi), two soil compaction treatments (compacted and noncompacted), and two soil moisture treatments (well watered and at soil water potential $\geq-1.5 \mathrm{MPa}$ ). Seedlings were planted in a Tropeptic haplorthox soil series in a series of soil columns consisting of $70 \mathrm{~cm}$ (28 in.) long sections of polyvinyl chloride [with internal diameter of $10 \mathrm{~cm}$ (4 in.)]. Each column contained two layers of soil. The lower layer was noncompacted, with an approximate bulk density of $1.0 \mathrm{~g} / \mathrm{cm}^{3}$, while the top layer was packed to a dry bulk density of $1.0 \mathrm{~g} / \mathrm{cm}^{3}$ or $1.5 \mathrm{~g} / \mathrm{cm}^{3}$ (Table 1). In total, eight different treatment combinations were used with 24-single plant replicates per treatment. Twelve days later, when the seedlings were well established (manifested by the appearance of new leaves), moisture stress was imposed by leaving half of the plants within each species unwatered, while the remaining half were watered daily. To determine soil water content, a 0 to $15 \mathrm{~cm}$ (0 to 6 in.) deep soil core was sampled with a punch $10 \mathrm{~mm}(0.4 \mathrm{in}$.) in diameter. Six samples were collected from each treatment. The soil core was weighed 
immediately and then oven dried at $105^{\circ} \mathrm{C}\left(221^{\circ} \mathrm{F}\right)$ to a constant weight. The soil water content was calculated as follows:

Soil water content $(\%)=100 \times($ fresh weight - dry weight $)$ fresh weight

For each plant, physiological measurements were made on fully expanded leaves with a LiCor 6200 Photosynthesis System (Lincoln, NE, U.S.). Twelve measurements were carried out. Stomatal conductance was expressed as a percentage of the control (well-watered and noncompacted). Immediately after measurement, the water potential of the same leaf was measured. Leaf discs, $6 \mathrm{~mm}$ (0.24 in.) in diameter, were sampled and quickly placed into thermocouple chambers, which were connected to a Wescor HR-33T dewpoint microvolmeter. A standard 2-hour incubation time at $25^{\circ} \mathrm{C}\left(77^{\circ} \mathrm{F}\right)$ was adopted before water potential readings were taken.

Table 1. Treatment combinations of bulk density and watering regimes.

\begin{tabular}{ll}
\hline Treatment & Descriptions of treatments \\
\hline WW & Well-watered at field capacity and noncompacted (control $1.0 \mathrm{~g} / \mathrm{cm}^{3}$ ) \\
WC & Well-watered at field capacity and compacted at bulk density $1.5 \mathrm{~g} / \mathrm{cm}^{3}$ \\
UN & Unwatered and noncompacted (control $1.0 \mathrm{~g} / \mathrm{cm}^{3}$ ) \\
UC & Unwatered and compacted at bulk density $1.5 \mathrm{~g} / \mathrm{cm}^{3}$ \\
\hline
\end{tabular}

Xylem sap was collected between 1400 and 1600 hours from detopped plants at the start of the experiment through the 12th day. Plants with intact root systems were taken out of PVC pipes, put in a large pressure chamber, and detopped about $20 \mathrm{~cm}$ (8 in.) from the base. The bark (with phloem tissues) $2 \mathrm{~cm}$ (0.8 in.) below the cut surface was removed carefully with a razor blade, and the cut surface was rinsed with distilled water. Collection pressures varied from $0.5 \mathrm{MPa}$ (for well-watered plants) to $1.5 \mathrm{MPa}$ (for unwatered plants). To avoid the contamination of the broken cells at the cut surface with phloem sap, the first $100 \mathrm{~mm}^{3}\left(0.006 \mathrm{in}^{3}\right)$ of sap were discarded, and the second 100 to $200 \mathrm{~mm}^{3}$ (0.006 to $0.12 \mathrm{in}^{3}$ ) were collected and stored in Eppendorf tubes at $-70^{\circ} \mathrm{C}\left(-94^{\circ} \mathrm{F}\right)$ pending $\mathrm{ABA}$ assay. After 12 days of drought, the collection of xylem sap was not carried out because the pressure needed to obtain xylem sap from unwatered plants exceeded the capabilities of the pressure chamber. Daily leaf samples for ABA analysis were also collected after measurements of stomatal conductance and water potential until the 21 st day. Leaves were harvested and plunged into liquid nitrogen. After being freeze dried, samples were stored in a dessicator until assay. The concentration of ABA was measured by a modification of used by Loveys (1984, Figure $1^{*}$ ).

\section{Data Analysis}

The data were subjected to two-way analysis of variance (ANOVA) using an SAS statistical package to determine the significance of the various factors and their interactions. Treatment means were separated using Duncan's new multiple-range test, at $\alpha=0.05$ level of significance.

\section{RESULTS AND DISCUSSION}

Analysis of variance (Table 2) showed that the three main factors significantly $(P<0.001)$ influenced leaf water potential, stomatal conductance, and leaf and xylem sap ABA of H. odorata and M. elengi seedlings. Stomatal conductance of stressed plants was significantly $(P<0.001)$ reduced three days after withholding water for both species (Figure 2a and b). With further decrease in soil water content, stomatal conductance decreased progressively to a minimum value of about 20\% for M. elengi and $40 \%$ for $\mathrm{H}$. odorata seedlings at the end of the experimental period relative to untreated control seedlings. With soil drying, significant reduction of stomatal conductance occurred earlier than the reduction of leaf water potential. Furthermore, the soil compaction treatment alone reduced stomatal conductance, indicating stomatal conductance is reduced in compacted soil, even without soil drying (Figure $3 a$ and $b$ ).

When plants were grown in compacted but well watered soil, the leaf water potential and leaf ABA concentration were similar, but the ABA concentration in the xylem sap increased three- to fivefold, and stomatal conductance was significantly reduced (Figure $3 \mathrm{c}$ and d). Furthermore, xylem sap and bulk leaf ABA concentration were significantly highly correlated with stomatal conductance in both species $\left(r^{2}=0.94\right.$ and 0.99 for M. elengi and H. odorata, respectively). However, leaf water potential and leaf ABA concentration were not significantly correlated $\left(r^{2}=0.16\right.$ and 0.03 for M. elengi and H. odorata, respectively).

As a stress signal, ABA plays a central role in the communication between roots and shoots, especially when the root system is under stress conditions (Davies and Zhang, 1991; Davies et al. 1994). However, this hypothesis has been challenged by several recent reports (Munns and King 1988; Munns 1990; Trejo et al. 1995). When plants were grown in a compacted soil, stomatal conductance was significantly reduced. Hartung et al. (1994) in the laboratory and Tardieu et al. (1992) under field conditions showed an increase in ABA concentration in the xylem sap of maize plants growing on compacted soil and observed a significant relationship between leaf growth rate or stomatal conductance and xylem sap ABA concentration, but not between leaf growth rate and the current leaf water status or the concentration of ABA in the bulk leaf. The same situation has been 
observed in the present study. When plants were grown in compacted but well-watered soil, the leaf water potential and leaf ABA concentration were almost unchanged, but the ABA concentration in the xylem sap increased three- to fivefold, and stomatal conductance was significantly lowered.

Mulholland et al. (1996) reported that changes in root and shoot growth of barley in compacted soil were accompanied by transitory increases in the xylem ABA during the early stages of growth. Similar responses were observed in this study, with the increase in the xylem sap ABA induced by compacted soil becoming most obvious at day 4. Xylem sap concentration, however, decreased in. M. elengi but remained almost constant in $H$. odorata seedlings after day 8 , suggesting that either the roots became increasingly adapted to the compacted soil or that there was a refractory period when the stimulus no longer promoted ABA biosynthesis and translocation (Knight et al. 1992).

Zhang and Davies (1990a, 1990b) have previously shown that stress-induced, root-sourced ABA may be detected more rapidly in the xylem sap than in the leaf extracts, a conclusion supported by this study, in which a substantial increase in xylem ABA was observed at high soil bulk density but by nonsignificant changes in foliar ABA. Mulholland et al. (1996) reported a subcritical bulk density that produced large differences in leaf expansion rates and leaves areas between two barley genotypes, Steptoe and Az34. The inability of Az34 to produce as much ABA compared to Steptoe in response to soil compaction may have been crucial to its failure to maintain near normal rates of leaf expansion at subcritical levels of compaction. A similar result was obtained from this study, whereby xylem sap $A B A$ of $M$. elengi was comparatively lower than in $H$. odorata seedlings.

\section{CONCLUSIONS}

The increase in xylem sap ABA concentration for both species observed at high bulk density was correlated with reduced stomatal conductance. These results suggest that xylem ABA may act as a stress signal in the control of stomatal conductance. Xylem ABA concentration were lower in M. elengi seedlings than in H. odorata seedlings. This finding may explain why M. elengi seedlings have lower urban stress tolerance than $H$. odorata.

\section{LITERATURE CITED}

Davies, W.J., and J. Zhang. 1991. Root signals and the development of plants growing in drying soil. Ann. Rev. Plant Physiol. Molec. Biol. 42:55-76.

Davies, W.J., F. Tardieu, and C.L. Trejo. 1994. How do chemical signals work in plants that grow in drying soil? Plant Physiol. 104:309-314.

Gowing, D.J.G.,H.G. Jones, and W.J. Davies. 1993. Xylemtransported abscisic acid: The relative importance of its mass and its concentration in the control of stomatal aperture. Plant Cell Environ. 16:453459.

Hartung, W., J. Zhang, and W.J. Davies. 1994. Does abscisic acid have a stress physiological role in maize plants growing in heavily compacted soil? J. Exper. Bot. 45:221226.

Knight, M.R., S.M. Smith, and A.J. Trewavas. 1992. Windinduced plant motion immediately increases cytosolic calium. Proc. National Academy of Sciences 89:49674971.

Lachno, D.R., R.S. Harrison-Murray, and L.J. Audus. 1982. The effects of mechanical impedance to growth on the level of ABA and IAA in root tips of Zea mays L. J. Exper. Bot. 33:943-951.

Liang, J., J. Zhang, and M.H. Wong. 1996. Stomatal conductance in relation to xylem sap ABA concentrations in two tropical trees, Acacia confusa and Litsea glutinosa. Plant Cell Environ. 19:93-100. 
Loveys, B.R. 1984. Diurnal changes in water relations and abscisic acid in field-grown Vitis vinifera cultivars. Ill. The influence of xylem-derived acid on leaf gas exchange. New Phytol. 98:563-573.

More, T.A., T. Stevens, and P.G. Allen. 1988. Valuation of urban parks. Landsc. Urban Plann. 15:139-152.

Mullholland, B.J., I.B. Taylor, C.R. Black, and J.A. Roberts. 1996. Effect of soil compaction of barley (Hordeum vulgare L.) growth. II. Are increased xylem sap ABA concentrations involved in maintaining leaf expansion in compacted soils? J. Exper. Bot. 47:551-556.

Munns, R. 1990. Chemical signals moving from roots to shoots: The case against ABA, pp 175-183. In Davies, W.J., and B. Jeftcoat (Eds.). Importance of Root to Shoot Communication in the Responses to Environmental Stress. Monograph 21. British Society for Plant Growth Regulation, Bristol, UK.

Munns R., and R.W. King. 1988. Abscisic acid is not the only stomatal inhibitor in the transpiration stream of wheat plants. Plant Physiol. 88:703-708.

Passioura, J.B. 1988. Root signals control leaf expansion in wheat seedlings growing in drying soil. Aust. J. Plant Physiol. 15:687-693.

Stypa, M.L. 1987. Effects of soil bulk density on seedling physiology and growth of corn (Zea mays L.). Ph.D. dissertation, University of Waterloo, Waterloo, ON.

Tardieu F., and W.J. Davies. 1992. Stomatal response to abscisic acid is a function of current plant water status. Plant Physiol. 98:540-549.

_. 1993. Integration of hydraulic and chemical signalling in the control of stomatal conductance and water status of droughted plants. Plant Cell Environ. 16:341-349.

Tardieu, F., J. Zhang, and W.J. Davies. 1992. What information is conveyed by a ABA signal from maize roots in drying field soil? Plant Cell Environ. 15:185-192.
Tardieu, F., N. Katerji, O. Bethenod, J. Zhang, and W.J. Davies. 1991. Maize stomatal conductance in the field: Its relationship with soil and plant water potentials, mechanical constraints and ABA concentration in the xylem sap. Plant Cell Environ. 14:308-314.

Trejo, C.L., A.L. Clephan, and W.J. Davies. 1995. How do stomata read abscisic acid: An effect of the mesophyll. Plant Physiol. 102:497-502.

Zhang, J., and W.J. Davies. 1990a. Changes in the concentration of ABA in the xylem sap as a function of changing soil water status can account for changes in leaf conductance and growth. Plant Cell Environ. 13:277-285. . 1990b. Does ABA in the xylem control the rate of leaf growth in soil-dried maize and sunflower plants? J. Exper. Bot. 41:1125-1132.

Acknowledgments. We thank Ong Kian Huat and Abdul Latib Senin for the technical help. Thanks are also extended to Assoc. Prof. Dr. Lim Meng Tsai for helpful suggestions, which greatly improved the manuscript. This work was part of a Ph.D project and was financed through IRPA and Universiti Putra Malaysia.

${ }^{1 *}$ Faculty of Resource Science and Technology

Universiti Malaysia Sarawak

94300 Kota Samarahan

Sarawak, Malaysia

${ }^{2}$ Faculty of Forestry

Universiti Putra Malaysia

43400 UPM Serdang

Selangor, Malaysia

*Corresponding author. 
Extract overnight in acetone with internal standards<smiles>[Tl]</smiles>

Evaporate to water phase in vacuo

$\downarrow$

Filter through nylon and adjust pH to 2.8

$\downarrow$

Partition $3 \times$ with diethyl ether

$\downarrow$

Reduce ether phase to dryness under $\mathbf{N}_{2}$ stream and redissolve in $0.5 \mathrm{~mL}$ ethanol

$\downarrow$

Pass through preconditioned $\mathrm{Cl}$ Sep-Pak, rinse with $5 \mathrm{~mL} \mathrm{H}_{2} \mathrm{O}$, and elute with $5 \mathrm{~mL}$ methanol

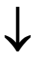

Concentrate methanolic extract to $1 \mathrm{~mL}$ under $\mathrm{N}_{2}$ stream, analyze by HPLC/salilylate for GCMS

Figure 1. Schematic representation of sample preparation method used in this study for HPLC and GCMS analysis of ABA (after Loveys 1984).

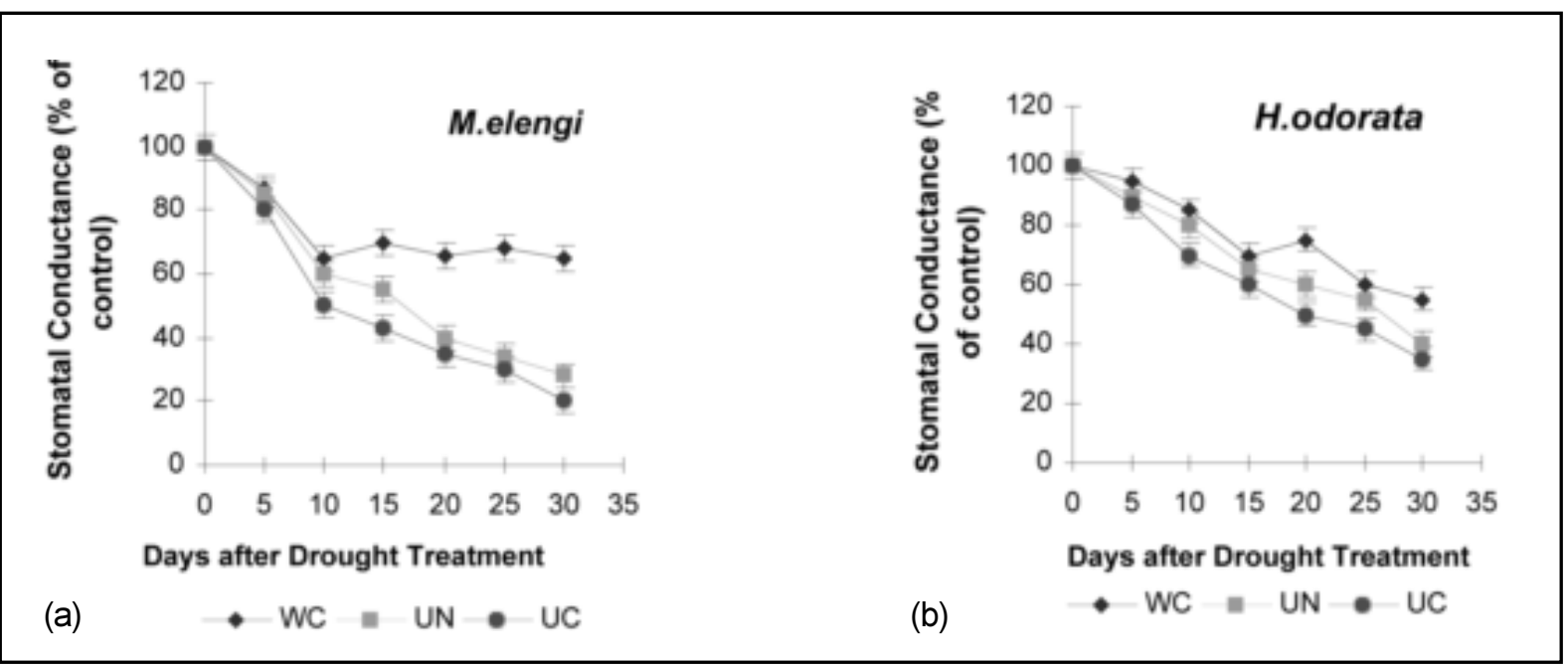

Figure 2. Stomatal conductance relative to noncompacted, well-watered control plants of (a) Mimusops elengi and (b) Hopea odorata seedlings following treatments. [WW = well-watered at field capacity and noncompacted (control $1.0 \mathrm{~g} / \mathrm{cm}^{3}$ ), WC = well-watered at field capacity and compacted at bulk density $1.5 \mathrm{~g} / \mathrm{cm}^{3}, \mathrm{UN}=$ unwatered and noncompacted $\left(\operatorname{control} 1.0 \mathrm{~g} / \mathrm{cm}^{3}\right), \mathrm{UC}=$ unwatered and compacted at bulk density $1.5 \mathrm{~g} / \mathrm{cm}^{3}$ ]. Vertical bars indicate standard error of the mean $(n=6)$. 


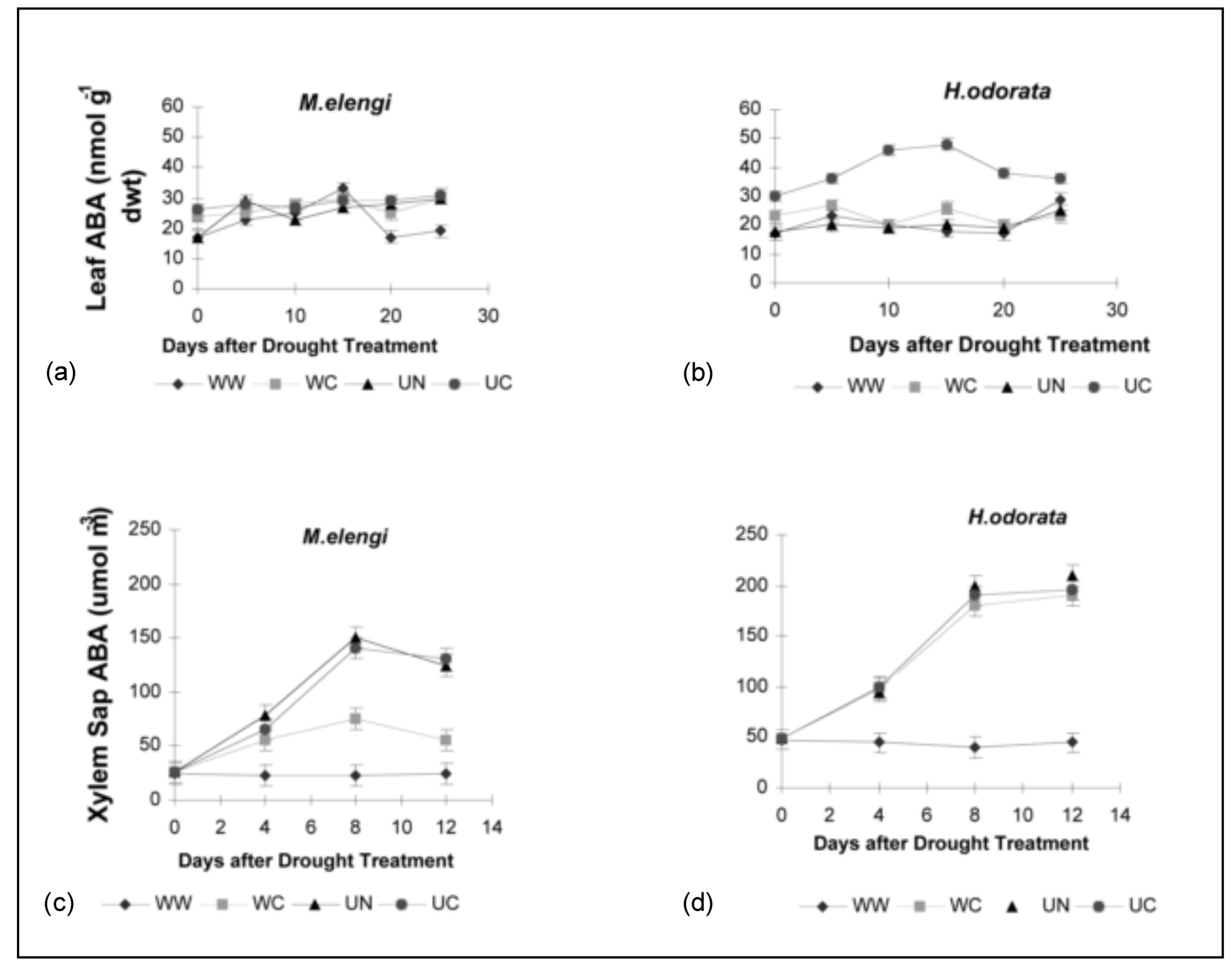

Figure 3. Changes in ABA concentration in the leaves and xylem sap of (a, c) Mimusops elengi and (b, d) Hopea odorata seedlings following treatments. [WW $=$ well-watered at field capacity and noncompacted $\left(\operatorname{control~} 1.0 \mathrm{~g} / \mathrm{cm}^{3}\right), \mathrm{WC}=\mathrm{well}^{-}$ watered at field capacity and compacted at bulk density $1.5 \mathrm{~g} / \mathrm{cm}^{3}, \mathrm{UN}=$ unwatered and noncompacted (control 1.0 $\left.\mathrm{g} / \mathrm{cm}^{3}\right), \mathrm{UC}=$ unwatered and compacted at bulk density $\left.1.5 \mathrm{~g} / \mathrm{cm}^{3}\right]$. Vertical bars indicate standard error of the mean $(n=6)$. 
Résumé. Lacide abcisique contenue dans la sève du xylème et celle dans les feuilles de Hopea odorata Roxb. et de Mimusops elengi L. a été mesurée dans des conditions de sol compacté et de sécheresse, et ce afin de vérifier le rôle de l'acide abcisique dans la régulation de la conductivité stomatale. Un rapide et substantiel accroissement en acide abcisique dans la sève du xylème mais non dans les feuilles a été corrélé avec l'assèchement du sol chez les deux espèces. Cependant, les concentrations en acide abcisique dans la sève du xylème étaient plus faibles chez les semis de $M$. elengi que chez ceux de H. odorata. Laccroissement en concentration d'acide abcisique dans la sève du xylème qui était observée dans les sols très compactés a été corrélée avec une diminution de la conductivité stomatale. Ces résultats suggèrent que l'acide abcisique du xylème pourrait agir comme un signal de stress dans le contrôle de la conductivité stomatale. Des niveaux réduits d'acide abcisique dans le xylème pourraient expliquer la tolérance plus faible au stress urbain des semis de M. elengi par rapport à ceux de H. odorata.

Zusammenfassung. Xylemsaft ABA und Blatt $A B A$ von Hopea odorata Roxb. und Mimusops elengi L. wurden unter den Bedingungen von Bodenverdichtung und Trockenheit gemessen, um die Rolle von ABA in der Regulation von Stomata-Leitfähigkeit zu erforschen. Eine schnelle und beträchtliche Erhöhung der Xylemsaft ABA Konzentration, aber nicht der Blatt ABA-Konzentration wurde bei beiden species mit trockenem Boden korreliert. Dennoch war die Xylem ABA Konzentration in M. elengi Sämlingen niedriger als in H. odorata Sämlingen. Der Anstieg der Xylemsaft ABA Konzentration, der bei starker Bodenverdichtung beobachtet wurde, wurde korreliert mit reduzierter Stomata-Leitfähigkeit. Diese Ergebnisse schlagen vor, dass Xylem ABA als ein Stresssignal bei der Kontrolle der Stomata-Leitfähigkeit eingesetzt werden könnte. Reduzierte Xylem ABA Level könnten die niedrigere Stresstoleranz von M. elengi gegenüber urbanen Stressfaktoren im Vergleich zu H. odorata erklären.

Resumen. La savia del xilema ABA y de la hoja ABA de Hopea odorata Roxb.y Mimusops elengi L. fueron medidas bajo condición de compactación del suelo y sequía para investigar el papel de ABA en la regulación de la conductancia estomatal. Un rápido y sustancial incremento en la concentración de ácido abscísico del xilema (ABA), pero no en la hoja, estuvo correlacionado con la sequía del suelo en las dos especies. Sin embargo las concentraciones de ABA del xilema fueron más bajas en brinzales de M.elengi que en los de H. odorata. El incremento en la concentración de la savia del xilema ABA, observado a alta densidad aparente del suelo, estuvo correlacionado con la reducida conductancia estomatal. Los niveles reducidos de ABA del xilema pueden explicar las menores tolerancia de los brinzales de M. elengi en relación a $H$. odorata. 